\title{
The Role of Recitation in the Process of English Learning for College Art Students
}

\author{
Zhipeng Liu* \\ School of foreign languages \\ Taishan University \\ Taian, Shandong, China
}

\begin{abstract}
Recitation--the traditional teaching method should be taken seriously again in English teaching. This is a survey report on the role of recitation in college art students' English learning. The research questions are: (1) Do you think recitation is useful for improving English? (2) Which recitation materials do you prefer to focus on, words, sentences, or articles? (3) Have your English teacher ever required for recitation and regular recitation? (4) Where did your recitation materials come? (5) What is the English result of the last final exam? According to the results of the survey, we come to the following conclusions: (1) College art students believe that recitation plays a positive role in improving their English level. (2) College art students think that recitation should be based on the text content while adding some extra-curricular materials to expand the scope of knowledge. (3) Recitation is a matter within students' duties, but teachers should regularly check the students' recitation, which will promote their le arning.
\end{abstract}

Keywords—recitation; English learning; questionnaire survey

\section{INTRODUCTION}

Currently, the communicative approach is pretty popular in English teaching in China. However, it is not entirely suitable for foreign language teaching in China, and it can't help to achieve obvious teaching effects, especially for art college students. During class, it is impossible to do large amount of communicative activities by means of limited input. If students are forced to communicate without enough input, a large number of irregular outputs will be produced. Moreover, foundation of art college students in high school English is relatively poor. The results of college entrance English are lower than those of other majors. If communicative approach is adopted, it will inevitably affect college English learning. Therefore, it is a rather good strategy for this kind of college students to adopt the traditional recitation language learning method. Professor Chen Lin (1999) pointed out that in the absence of a linguistic environment, foreign languages can not be "acquired" and can only be "learned". Not only children, but also adults work hard, Professor Chen Lin said. [1] In accordance with Professor Zhang Weiyou (2002), in retrospect, his English proficiency is largely due to the pastorate learning and there is no shortcut in English learning.[2] Professor Hu Wenzhong (1989) also said that teenagers should give full play to the advantages of their memory and recite more dialogues and texts to learn a foreign language well. Some teaching Legalists oppose recitation, while he thought foreign languages should be more memorable.[3] Nowadays, computer-based multimedia teaching method is widely used in College English learning and teaching, which is exerting a revolutionary influence on College English teaching. But under the conditions of multimedia teaching, is it necessary to carry out the traditional reciting method? Through some experimental data, this paper reveals the role of recitation in the English learning process of college art students, aiming at providing some theoretical basis for modern college English teaching.

\section{THEORETICAL BASIS}

According to applied linguist Krashen's (1987), language acquisition is accomplished through language input, and the main focus of teaching should be on providing students with the best language input [4]. Recitation input is in conformity with Krashen's theory of language input. Students can enhance their understanding of grammatical knowledge, learn to express their ideas in native English, get rid of the negative influence of their mother tongue, and finally improve their writing ability and standardize their language output through recitation input.

Recitation input can improve English learners' sense of language. Bialystok (1978), a Canadian linguist, classifies foreign language learners' linguistic knowledge into explicit linguistic knowledge and implicit linguistic knowledge[5]. Explicit language knowledge refers to all the language knowledge of the target language in the learner's consciousness, including phonetics, grammar and vocabulary, which exists in the learner's consciousness and can be clearly expressed. Implicit linguistic knowledge refers to the internalized linguistic knowledge, existing in the learner's subconscious level, which means that learners may not be able to express it clearly. But using language without thinking is a common sense of language. The implication of the linguist Bialystok's theoretical model of second language learning is that 'the more implicit language knowledge a person has, the higher his proficiency in using the target language" [6] (Ma Guanghui, 1997).

Recitation input strengthens the accumulation and consolidation of students' linguistic knowledge, thus transforming explicit linguistic knowledge into implicit linguistic knowledge[7] (Cao Yilu, 1999). Students' sense of language is also formed, which is bound to promote their language acquisition. 


\section{Questionnaire SuRvey}

\section{A. Research Problems}

This survey attempts to make art students answer the following five questions: (1) Do you think recitation is useful for improving English? (2) Which recitation materials do you prefer to focus on, words, sentences, or articles? (3) Have your English teacher ever required for recitation and regular recitation? (4) Where did your recitation materials come? (5) What is the English result of the last final exam?

\section{B. Research Object}

The following is the number and distribution of participants of the survey.

TABLE I. NUMBER AND DIST RIBUTION OF RESPONDENTS

\begin{tabular}{|c|c|c|c|c|c|}
\hline \multicolumn{2}{|c|}{ Musicology } & \multicolumn{2}{c|}{ Fashion design } & \multicolumn{2}{c|}{ Fine Arts } \\
\hline \multicolumn{2}{|c|}{39} & \multicolumn{2}{c|}{41} & \multicolumn{2}{c|}{38} \\
\hline $\begin{array}{c}\text { Second } \\
\text { grade }\end{array}$ & $\begin{array}{c}\text { First } \\
\text { grade }\end{array}$ & $\begin{array}{c}\text { Second } \\
\text { grade }\end{array}$ & $\begin{array}{c}\text { First } \\
\text { grade }\end{array}$ & $\begin{array}{c}\text { Second } \\
\text { grade }\end{array}$ & $\begin{array}{c}\text { First } \\
\text { grade }\end{array}$ \\
\hline 23 & 16 & 17 & 24 & 25 & 13 \\
\hline
\end{tabular}

All the subjects were from grade one or two in the Art Department of our university, and 118 students participated in the survey. It can be seen from the figures in the chart above, the distribution of students taking part in the survey is more reasonable. The objects were more representative. Therefore, the results of the survey should basically meet the needs of the study, that is, to understand the correlation between recitation and English learning.

\section{Research Tools and Methods}

The survey tool is a questionnaire consisting of 5 small questions (see Appendix). The questionnaire was conducted by the author in class. A total of 118 questionnaires were collected, all of which were valid questionnaires.

\section{Results}

Our main purpose is to understand the general situation of the correlation between English recitation and English achievement of art students, therefore, we only generalize and analyze the results obtained without making specific distinctions between grades. We get the following results through collation of the collected data:

1) Do you think recitation is useful for improving English?

Among the students who received the questionnaire, the percentages of very useful and useful are $100 \%, 100 \%$, $94.73 \%$ respectively. Therefore, art students are positive about recitation. The concrete results are as follows:

TABLE II. WHETHER RECIT ATION IS USEFUL TO IMPROVE ENGLISH

\begin{tabular}{|c|c|c|c|c|c|}
\hline & $\begin{array}{c}\text { Very } \\
\text { useful }\end{array}$ & Useful & Useless & $\begin{array}{c}\text { Not at all } \\
\text { useful }\end{array}$ & In total \\
\hline Musicology & 20 & 19 & 0 & 0 & 39 \\
\hline Percentage & $51.28 \%$ & $48.72 \%$ & $0 \%$ & $0 \%$ & $100 \%$ \\
\hline $\begin{array}{c}\text { Fashion } \\
\text { design }\end{array}$ & 23 & 18 & 0 & 0 & 41 \\
\hline Percentage & $56.10 \%$ & $43.90 \%$ & $0 \%$ & $0 \%$ & $100 \%$ \\
\hline Fine Arts & 21 & 15 & 2 & 0 & 38 \\
\hline Percentage & $55.26 \%$ & $39.47 \%$ & $5.27 \%$ & $0 \%$ & $100 \%$ \\
\hline
\end{tabular}

2) Which recitation materials do you prefer to focus on, words, sentences, or articles?

Among the students surveyed, the three majors had different tendencies towards recitation. Music majors students preferred to recite word (64.10\%), followed by sentences (25.64\%) and articles (10.26\%). Fashion design majors preferred to recite articles (48.74\%) more frequently, followed by vocabulary (26.83\%) and sentences (24.39\%). Art majors and music majors preferred to recite words (50\%), sentences (34.21\%) and articles (15.38\%). In general, students majoring in fashion design are more interested in reciting sentences and articles, while students majoring in music and art are more interested in reciting vocabulary. The concrete results are as follows:

TABLE III. WHICH RECIT ATION MATERIALS DO YOU PREFER TO FOCUS ON, WORDS, SENTENCES, OR ARTICLES?

\begin{tabular}{|c|c|c|c|c|}
\hline & Words & Sentences & Articles & In total \\
\hline Musicology & 25 & 10 & 4 & 39 \\
\hline Percentage & $64.10 \%$ & $25.64 \%$ & $10.26 \%$ & $100 \%$ \\
\hline $\begin{array}{c}\text { Fashion } \\
\text { design }\end{array}$ & 11 & 10 & 20 & 41 \\
\hline Percentage & $26.83 \%$ & $24.39 \%$ & $48.78 \%$ & $100 \%$ \\
\hline Fine Arts & 19 & 13 & 6 & 38 \\
\hline Percentage & $50 \%$ & $34.21 \%$ & $15.38 \%$ & $100 \%$ \\
\hline
\end{tabular}

3) Have your English teacher ever required for recitation and regular recitation?

Whether the teacher asked to recite and check will differ due to their majors. The proportion of apparel design teachers required recitation and regular examination was the highest $(65.85 \%)$, while the proportion of art and music majors were $36.84 \%$ and $23.08 \%$, respectively. Among the data required by teachers to recite, but do not check regularly, the proportion of the three majors was $71.79 \%$ (musicology), 52.63\% (art major) and $34.15 \%$ (fashion design). But generally speaking, most of the teachers require students to recite English, and the teachers who teach clothing design can check students' recitation more often. The concrete results are as follows:

TABLE IV. WHETHER TO ASK FOR MEMORIZATION AND CHECK THE BACKS ON A REGULAR BASIS

\begin{tabular}{|c|c|c|c|c|}
\hline & $\begin{array}{c}\text { Require } \\
\text { recitation } \\
\text { without } \\
\text { periodic } \\
\text { inspection }\end{array}$ & $\begin{array}{c}\text { Require } \\
\text { recitation } \\
\text { and regular } \\
\text { inspection }\end{array}$ & $\begin{array}{c}\text { No } \\
\text { requirement } \\
\text { for recitation } \\
\text { nor periodic } \\
\text { examination }\end{array}$ & In total \\
\hline Musicology & 28 & 9 & 2 & 39 \\
\hline Percentage & $71.79 \%$ & $23.08 \%$ & $5.13 \%$ & $100 \%$ \\
\hline $\begin{array}{l}\text { Fashion } \\
\text { design }\end{array}$ & 14 & 27 & 0 & 41 \\
\hline Percentage & $34.15 \%$ & $65.85 \%$ & $0 \%$ & $100 \%$ \\
\hline Fine Arts & 20 & 14 & 4 & 38 \\
\hline Percentage & $52.63 \%$ & $36.84 \%$ & $10.53 \%$ & $100 \%$ \\
\hline
\end{tabular}

\section{4) Where did your recitation materials come?}

According to the survey data of recitation materials, nearly half of the students in the three majors believed that recitation should be based on texts and supplemented by extracurricular materials, the proportions of which were $50 \%$ (art), 46.39\% (fashion design) and 41.03\% (musicology). It can be seen that students are not only satisfied with the content 
of the text to learn and recite, but also eager to learn extracurricular knowledge to broaden the scope of knowledge.

TABLE V. SOURCE OF RECIT ATION MATERIALS

\begin{tabular}{|c|c|c|c|c|c|}
\hline & Text mainly & Extracurricular supplement & $\begin{array}{l}\text { Supplemented by } \\
\text { extracurricular activities, and } \\
\text { texts are the main ones }\end{array}$ & $\begin{array}{l}\text { Extracurricular activities, } \\
\text { supplemented by texts }\end{array}$ & In total \\
\hline Musicology & 15 & 4 & 16 & 4 & 39 \\
\hline Percentage & $38.46 \%$ & $10.26 \%$ & $41.03 \%$ & $10.25 \%$ & $100 \%$ \\
\hline Fashion design & 14 & 3 & 19 & 5 & 41 \\
\hline Percentage & $34.15 \%$ & $7.26 \%$ & $46.39 \%$ & $12.20 \%$ & $100 \%$ \\
\hline Fine Arts & 16 & 2 & 19 & 1 & 38 \\
\hline Percentage & $42.11 \%$ & $5.26 \%$ & $50 \%$ & $2.63 \%$ & $100 \%$ \\
\hline
\end{tabular}

5) What is the English result of the last final exam?

Among the students surveyed, 46.34\% (major in fashion design), $13.16 \%$ (major in fine arts) and $10.25 \%$ (major in musicology) had excellent scores ( $>80)$. It can be seen that the number of outstanding students majoring in fashion design is much higher than the other two majors, nearly half of the total number. The concrete results are as follows:

TABLE VI. ENGLISH RESULT OF LAST FINAL EXAM

\begin{tabular}{|c|c|c|c|c|c|}
\hline & $\leq 59$ & $60-69$ & $70-79$ & $\geq 80$ & In total \\
\hline Musicology & 1 & 19 & 15 & 4 & 39 \\
\hline Percentage & $2.56 \%$ & $48.72 \%$ & $38.46 \%$ & $10.25 \%$ & $100 \%$ \\
\hline $\begin{array}{c}\text { Fashion } \\
\text { design }\end{array}$ & 2 & 6 & 14 & 19 & 41 \\
\hline Percentage & $4.88 \%$ & $14.63 \%$ & $34.15 \%$ & $46.34 \%$ & $100 \%$ \\
\hline Fine Arts & 0 & 12 & 21 & 5 & 38 \\
\hline Percentage & $0 \%$ & $31.58 \%$ & $55.26 \%$ & $13.16 \%$ & $100 \%$ \\
\hline
\end{tabular}

\section{E. Discussion}

In accordance with the foregoing research results, we attempt to analyze and explain the results as follows.

\section{1) Function of recitation}

The survey results showed that: art students hold a positive attitude towards the role of recitation, but they hold different views on the types of recitation. Most music majors and art majors only like to recite vocabulary, but ignore the recitation of sentences and articles and other materials. While students of fashion design major are just the opposite, they prefer to recite sentences and articles. In the English final examination, the students of fashion design major are significantly better than those of other majors. Therefore, we can make a conjecture that reciting textual materials such as articles and sentences is more conducive to improving English performance than just reciting vocabulary.

\section{2) The source of material for recitation}

The results of the questionnaire survey showed that most art students believe that recitation should be based on text content and during which, some extracurricular materials should be added. This reflects that students want to increase their extracurricular knowledge and broaden their scope of knowledge while learning the text well.

\section{3) Recitation requirements and inspection}

According to the survey data, English teachers who teach art students can ask students to recite English, but some teachers do not do enough to check students' recitation regularly.
Fundamentally, students' learning English depends on their attitude towards learning English, that is, internal factors. Internal factors are decisive factors, but external factors also contribute to internal factors, which require teachers to supervise and guide students and give play to the external role of teachers in students' learning. For example, the teachers who teach clothing design are more likely to check their students' recitation, so their English scores are significantly better than those of the other two majors. Teachers should check students' recitation regularly and guide them so that students can enhance their sense of language and learn English well.

\section{CONCLUSION}

Based on the above data, we can draw the following conclusions and suggestions:

1. Function of recitation: Art students believe English recitation has a positive effect on their English proficiency.

2. The source of material for recitation: Art students believe that recitation should be based on text content and some extracurricular materials should be added. So teachers should choose passages that are closely related to the content of the text, fluent in writing and beautiful in language for students to recite. Meantime, extracurricular materials that are suitable for students to memorize should be found for students to memorize and play the guiding role of teachers.

3. Recitation requirements and inspection: Students are the main body of recitation and English recitation is done by students themselves finally. But teachers should urge them to recite and give some guidance. Recitation should be based on sentences and articles and text memory will better promote students' English proficiency. He Jianing (2006) pointed out that if one recites words in the vocabulary in isolation, he would get little[8] since it actually equates every foreign language word with a native language word and isolates it from the language and context.[9](GUI Shi Chun, 1988)

\section{REFERENCES}

[1] Chen Lin. English experts say (column) [J]. English learning, 1999 (6): 1.

[2] Zhang Weiyou. English experts say (column) [J]. English learning, 2002 (1): 1.

[3] Hu Wenzhong. Teaching and Learning in English [M]. Beijing: Foreign Language Teaching and Research Press, 1989. 
[4] Krashen S. Principles and Practice in Second Language Acquisition [M]. Hertfordshire: Prentice Hall International (UK) Ltd, 1987: 21-25

[5] Bialystok E. A Theoretical Model of Second Language Learning[J]. Language Learning, 1978(28).

[6] Ma Guanghui. Bialystok's Language Learning Model [J]. Foreign Language Teaching, 1997(1): 8-9.
[7] Cao Yilu. Foreign Language Teaching Should Draw Lessons from Chinese Traditional Language Teaching Experience [J]. Foreign Languages, 1999 (2).

[8] He Jianing. Investigation Report on College Students' English Reciting[J]. Shandong Foreign Language Teaching, 2006, (1).

[9] Gui Shichun. Applied Linguistics [M]. Changsha: Hunan Education Press, 1998.

\section{Appendix: Questionnaire}

(1) Do you think recitation is useful for improving English?

(A) Very useful (B) Useful (C) Useless (D) Not at all useful

(2) Which recitation materials do you prefer to focus on, words, sentences, or articles?

(A) Word (B) Sentence (C) Article

(3) Have your English teacher ever required for recitation and regular recitation?
(A) Require recitation without periodic inspection
(B) Require recitation and regular inspection
(C) No requirement for recitation nor periodic examination

(4) Where did your recitation materials come from?
(A) Text mainly
(B) Extracurricular supplement
(C) Supplemented by extracurricular activities and texts are the main ones
(D) Extracurricular activities, supplemented by texts

(5) What is the English result of the last final exam? 